\title{
Carbon Content in Shrub-tree Species of the Caatinga
}

\author{
Mayara Dalla Lana ${ }^{1}$ (D), Rinaldo Luiz Caraciolo Ferreira² (D), \\ José Antônio Aleixo da Silva ${ }^{2}$ (D), Gustavo Pereira Duda ${ }^{3}$ (D), \\ German Hugo Gutierrez Cespedes ${ }^{4}$
}

${ }^{1}$ Curso Técnico em Meio Ambiente, Instituto Federal de Ciência e Tecnologia de Pernambuco - IFPE, Garanhuns/PE, Brasil

${ }^{2}$ Departamento de Ciências Florestais, Universidade Federal Rural de Pernambuco - UFRPE, Recife/PE, Brasil ${ }^{3}$ Unidade Acadêmica de Garanhuns - UAG, Departamento de Agronomia, Universidade Federal Rural de Pernambuco - UFRPE, Garanhuns/PE, Brasil

${ }^{4}$ Agro Industrial Mercantil Excelsior S/A - AGRIMEX, Goiana/PE, Brasil

\begin{abstract}
The aim of this study was to determine the carbon content $(C)$ in stem, leaves and thin and thick branches of eight species in an area of Caatinga, municipality of Floresta, Pernambuco, Brazil. To do so, dry biomass samples of at least 15 trees distributed into five diametric classes collected from the study area and fractionated in laboratory were used for each of the eight evaluated species. Carbon content was determined using CHNS/O elemental analyzer. Average carbon content of $46.4 \%$ is recommended for Anadenanthera colubrina, Aspidosperma pyrifolium, Bauhinia cheilantha, Cnidoscolus quercifolius, Mimosa ophthalmocentra and Mimosa tenuiflora, without need for specific values for each compartment. Croton heliotropiifolius and Poincianella bracteosa require distinct values per compartment for individuals in order to avoid trends in carbon stock estimates.
\end{abstract}

Keywords: climate change, carbon projects, sustainable management. 


\section{INTRODUCTION}

The increase in greenhouse gas concentrations, mainly carbon dioxide $\left(\mathrm{CO}_{2}\right)$ in the atmosphere and its influence on global climate change processes, have aroused great interest in studies on biological carbon fixation (C) in plants and soil as a way to mitigate this environmental impact. In Brazil, for example, the annual estimate of greenhouse gas emissions (GHG) between years 2005 and 2012 showed that changes in land use and forests have contributed to $15 \%$ of total emissions (Brasil, 2014).

Basic strategies for assessing the potential for mitigating carbon emissions by natural ecosystems require the following information: (i) land availability; (ii) amount of carbon that can be sequestered and conserved in vegetation and soil; and (iii) the period of time carbon will be stored at each site (Brown, 1996).

To estimate the amount of carbon sequestered and conserved in vegetation, two types of data are used: dry biomass and carbon content (C\%) of each tree compartment (roots, stems, branches and leaves) (Thomas \& Martin, 2012). Both present some type of difficulty regarding obtaining good level of precision and reliability, demanding robust and reliable estimation strategies.

For dry biomass, direct methods such as inventory and felling and weighing of the parts of all trees present more accurate information; however, costs and the large areas make this strategy unfeasible. Another option are indirect methods such as the use of remote sensing with calibration through field measurements and allometric equations; however, the errors of these options require careful use for estimating carbon in different areas, despite generating more reliable estimates (Gonzalez et al., 2014).

Carbon content is one of the most important plant characteristics and is critical for evaluating the global carbon cycle (Ma et al., 2017), but its determination presents high cost due to the large number of species found in forest phytophysiognomies, which represents very important information since numerous studies point out statistical differences within and among species (Elias \& Potvin, 2003; Lamlom \& Savidge, 2003; Weber et al., 2006; Vieira et al. 2009; Martin \& Thomas, 2011; Watzlawick et al., 2011; Thomas \& Martin, 2012; Pereira et al., 2016; Ma et al., 2017).
In addition, overall fixed value of $50 \%$ has been used in carbon sequestration estimates in vegetation due to the lack of accurate information on carbon contents of species, leading to under or overestimated stock values compared to real values in carbon credit projects (Laiho \& Laine, 1997; Sanquetta, 2002; Elias \& Potvin, 2003; Koehler et al., 2005; Thomas \& Malczewski, 2007; Thomas \& Martin, 2012; Ma et al., 2017).

One of the forest phytophysiognomies with very scarce studies related to the carbon content of its floristic composition is the Caatinga (Vieira et al. 2009; Pereira et al., 2016). This biome covers $11 \%$ of the Brazilian territory and has great variety of plants that distinguish it from the other groups that form Brazilian typologies, with high number of species and forest fragments that are still preserved (Giulietti et al., 2004; Sampaio, 2010).

For Sampaio \& Costa (2011), this biome has high potential for obtaining financial resources through carbon credits; however, the scarcity of scientific research compromises the understanding and precision of the $\mathrm{CO}_{2}$ conversion process in this ecosystem, underestimating its importance in the global carbon market. More information on this subject is needed in order to improve the understanding of the carbon storage potential and flow in the Caatinga, and thus to predict future scenarios of sustainable management.

Therefore, the aim of this study was to determine the carbon content present in the main compartments (stem, leaves and branches) of species with the highest absolute density (individuals.ha ${ }^{-1}$ ) in an area of Caatinga, testing the hypothesis that there are statistical differences among C\% values, not being possible to consider an average value per species, or for a group of species or compartments of the same species.

\section{MATERIAL AND METHODS}

\subsection{Study area}

The present study was carried out in a typical area of the Caatinga in the sertão Pernambucano with about 50 ha ( $8^{\circ} 30^{\prime} 37^{\prime \prime S}$ and $37^{\circ} 59^{\prime} 07^{\prime \prime}$ W) within Fazenda Itapemirim owned by Agrimex Agroindustrial Excelsior S. A, which has total extension of approximately 6,000 ha and is located in the municipality of Floresta, state of Pernambuco (Figure 1). 


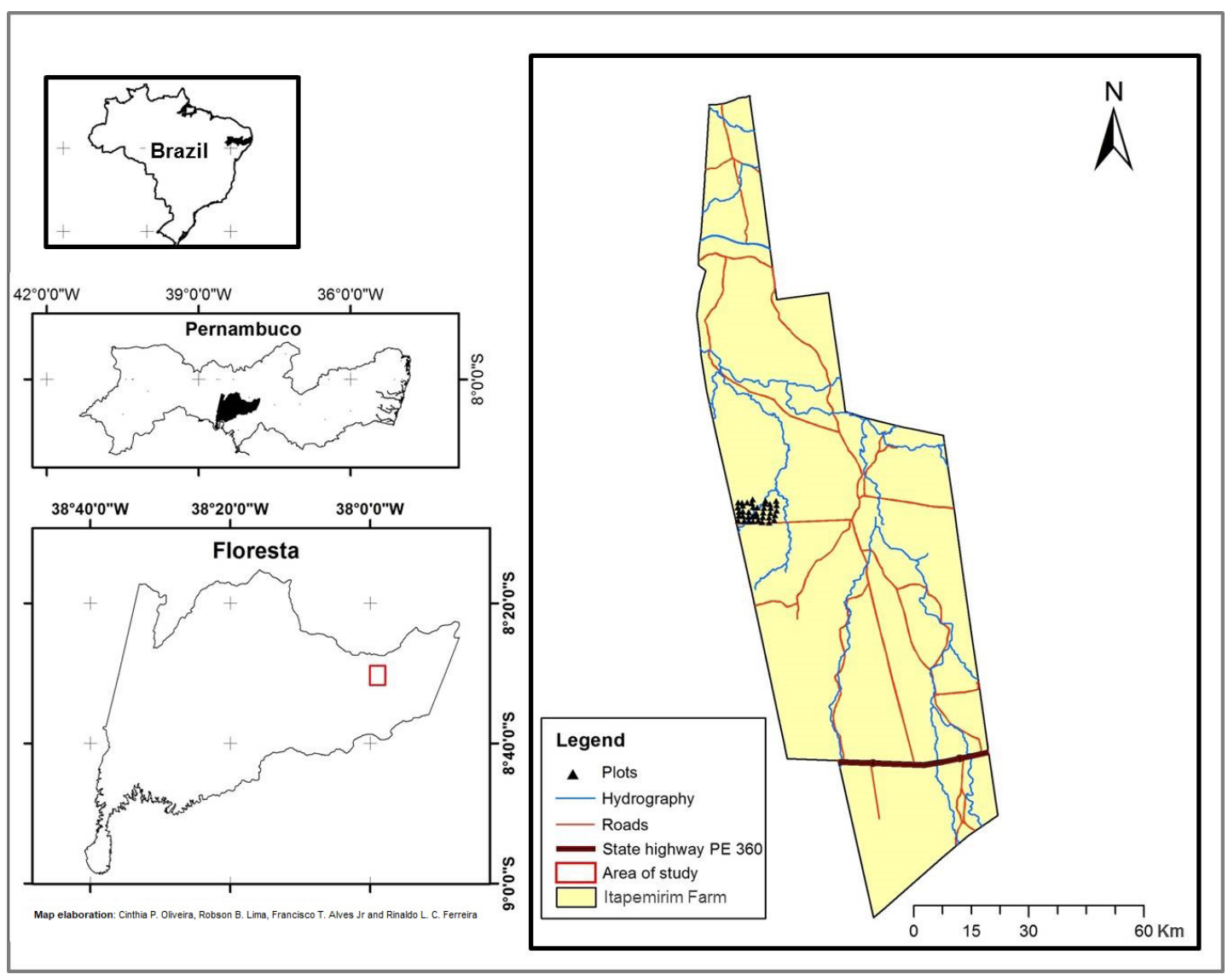

Figure 1. Location of the study area in the municipality of Floresta. state of Pernambuco, Brazil. Source: Lima et al. (2017).

The vegetation occurring in the region can be classified as Wooded Steppe Savannah (Savana-Estépica Arborizada) divided into two strata: upper shrub-tree, sparse; and the other, lower grassy-woody (IBGE, 2012). Soil is classified as Chronicus Luvisols, characterized by being shallow and presenting abrupt texture changes (EMBRAPA, 2011).

The climate of the region is BS' $\mathrm{h}$ according to the Köppen climate classification, which refers to a hot semi-arid climate characterized by aridity and water deficiency, with average annual rainfall of approximately $503 \mathrm{~mm}$, rainy season from December to April and average annual temperatures of $26.1^{\circ} \mathrm{C}$ according to temperature and precipitation data between months of January to December for the municipality of Floresta-PE, provided by the Institute of Technology of Pernambuco (ITEP) between years 1980 and 2010 (Alves et al., 2013).

\subsection{Sampling and data collection}

The study history in the 50 ha area refers to systematic sampling with the establishment and monitoring of 40 permanent $20 \times 20 \mathrm{~m}$ plots $\left(400 \mathrm{~m}^{2}\right)$ since the year 2008, according to methodology proposed by the Forest Management Network of the Caatinga (Comitê Técnico Científico da Rede de Manejo Florestal da Caatinga, 2005), which are $80 \mathrm{~m}$ awayfrom each another, $50 \mathrm{~m}$ from the border, and total sample area of $1.6 \mathrm{ha}$. According to Fazenda Itapemirim employees' reports, the site is considered preserved, since there is no history of clear cutting for firewood or wood exploitation, with the removal of only a few forest products for eventual maintenance of fences that demarcate the farm and animal grazing, mainly goats, in an extensive and uncontrolled manner.

For plot installation in 2008, all individuals with circumference at $1.30 \mathrm{~m}(\mathrm{CBH}) \geq 6 \mathrm{~cm}$ were identified 
and labeled on their $\mathrm{CBH}$, aiming to standardize the measurement site (Comitê Técnico Científico da Rede de Manejo Florestal da Caatinga, 2005). Measurements were performed again in 2011, 2012 and 2013, and recruited individuals were included in the database, i.e., those that reached the minimum $\mathrm{CBH}$ stipulated in the re-measurement years; and dead and fallen trees were also recorded.

The eight plants of the 24 species recorded in the study area during five years with the highest absolute density were selected (individuals.ha-1) for analyses based on the phytosociological inventory carried out in the year 2013. These species represent $91.6 \%$ of the total density of the study area, which is 3431.3 ind. $\mathrm{ha}^{-1}$, considering that an individual corresponds to a stem that can come from sprouts or bifurcations below $0.30 \mathrm{~m}$ in height.

Species and their respective absolute densities are the following: Anadenanthera colubrina var. cebil (Griseb.) Altschul (angico) with 79.4 ind. ha ${ }^{-1}$, Aspidosperma pyrifolium Mart. (pereiro) with 301.9 ind. ha ${ }^{-1}$, Bauhinia cheilantha (Bong.) Steud. (mororó) with 130.6 ind. ha ${ }^{-1}$, Cnidoscolus quercifolius Pohl (faveleira) with 90.6 ind. ha ${ }^{-1}$, Croton heliotropiifolius Kunth (quebra-faca) with 100.6 ind. ha ${ }^{-1}$, Mimosa ophthalmocentra Mart. ex Benth (jurema de embira) with 380.6 ind. ha ${ }^{-1}$, Mimosa tenuiflora (Willd.) Poir. (jurema preta) with 70.6 ind. ha ${ }^{-1}$ and Poincianella bracteosa (Tul.) L. P. Queiroz. (catingueira) with 1989.4 ind. ha ${ }^{-1}$. Nomenclatures follow the pattern suggested by the Angiosperm Philogeneny Group III (APG III, 2009).

\subsection{Carbon content determination}

Green aerial biomass samples were collected in order to determine the $\mathrm{C} \%$ in the compartments of stem, leaves, thick branches (circumference $>6 \mathrm{~cm}$ ) and thin branches ( $\leq 6 \mathrm{~cm}$ circumference) of the eight species. Collections were performed based on the amplitude of circumferences found in the study area (Alves et al., 2017).

Each species had at least 15 individuals sampled in 5 the circumference classes at $1.30 \mathrm{~m}$ from the soil (CBH), with amplitudes of $6 \mathrm{~cm}$ based on the $\mathrm{CBH}$ of at least $6 \mathrm{~cm}$. Classes and amplitudes $(\mathrm{cm})$ are the following: Class I $(6.0-12.0 \mathrm{~cm})$; Class II $(12.1-18.0 \mathrm{~cm})$; Class III (18.1-24.0 cm); Class IV $(24.1-30.0 \mathrm{~cm})$ and Class V $(>30.0 \mathrm{~cm})$. The same number of individuals (3) was not found for all $\mathrm{CBH}$ classes $(\mathrm{cm})$ during data collection for A. pyrifolium, B. cheilantha, C. heliotropiifolius and M. ophthalmocentra. By analyzing information from the 40 permanent plots during the five years of measurement, it was found that $B$. cheilantha and $C$. heliotropiifolius presented maximum $\mathrm{CBH}$ of 14 and $13 \mathrm{~cm}$, respectively, while only five individuals for A. pyrifolium and M. ophthalmocentra had $\mathrm{CBH}$ greater than $30 \mathrm{~cm}$. As sampling tends to be representative of the entire population, the difficult in finding individuals of these species among all analyzed classes becomes evident (Table 1).

The felling of individual trees was carried out in field close to permanent plots. This field is authorized for cutting by the Agência Estadual de Meio Ambiente de Pernambuco ( $\mathrm{CPRH})$, via management plan. The choice of individuals was randomly performed, avoiding partial cut, burned or fallen trees.

After felling, individual trees were separated into the following compartments: stem, leaves, thin branches (circumference $<6 \mathrm{~cm}$ ) and thick branches (circumference $\geq 6 \mathrm{~cm}$ ), and then weighed using portable digital scale (wet weight in $\mathrm{kg}$ ). A sample was collected from each compartment and weighed in the

Table 1. Number of arboreal individuals per $\mathrm{CBH}$ class $(\mathrm{cm})$ of the eight species evaluated in an area of Caatinga in the municipality of Floresta, state of Pernambuco, Brazil.

\begin{tabular}{lccccccc|}
\multicolumn{1}{c}{ Species } & \multicolumn{7}{c}{ Number of arboreal individuals per CBH class $(\mathbf{c m})$} \\
\cline { 2 - 7 } & I & II & III & IV & V & Total \\
A. colubrina & 3 & 3 & 3 & 3 & 3 & 15 \\
A. pyrifolium & 3 & 3 & 4 & 4 & 1 & 15 \\
B. cheilantha & 18 & - & - & - & - & 18 \\
C. quercifolius & 3 & 3 & 3 & 3 & - & - & 15 \\
C. heliotropiifolius & 18 & - & - & 4 & 2 & 18 \\
M. ophthalmocentra & 3 & 3 & 3 & 3 & 3 & 15 \\
M. tenuiflora & 3 & 3 & 3 & 3 & 3 & 15 \\
P. bracteosa & 3 & 3 & 3 & & & 15 \\
\hline
\end{tabular}


field (sample wet weight in $\mathrm{kg}$ ). In the case of stems, the sample was represented by a small piece of $20 \mathrm{~cm}$ of its length removed from $1.30 \mathrm{~m}$ above the ground.

All wet samples were labeled and taken to the Laboratory of Dendrology, Department of Forest Engineering Federal Rural University of Pernambuco (UFRPE), where they were dried in forced air circulation oven at temperature of $70^{\circ} \mathrm{C}$ until dry weight stabilization $(\mathrm{kg})$. Subsequently, dried biomass samples from each species were fractionated and ground in mill with metallic sieves until reaching powder consistency, being then weighed again and stored in plastic containers identified by species and their respective compartment.

Table 2 shows the number of samples for carbon analysis per compartment for each species analyzed. Species A. colubrina, A. pyrifolium, C. quercifolius, M. ophthalmocentra, M. tenuiflora and P. bracteosa had approximately 15 samples per compartment analyzed, while $B$. cheilantha and $C$. heliotropiifolius had 18 samples each.

It was observed that the number of collected samples varies according to species for the thick branch compartment, since not all shrub-tree individuals have branches with circumference $\geq 6 \mathrm{~cm}$, especially smaller species and those among lower $\mathrm{CBH}$ classes $(\mathrm{cm})$. Differences in the other compartments were caused by problems related to sample storage and control, with loss of 9 stem and thin branch samples (Table 2).

Carbon content was determined at the Laboratory of Soil Fertility of UFRPE-Unidade Acadêmica Garanhuns (UFRPE-UAG) with the aid of CHNS/O elemental analyzer, which is a modern equipment equipped with analyzer, printer and ultramicro balance Perkin-Elmer
AD-6. One gram of sample undergoes total combustion $\left(1000^{\circ} \mathrm{C}\right)$ in this equipment, and an infrared sensor detects the amount of $\mathrm{CO}_{2}$ generated by this process, associating it to the amount of elemental carbon present in the sample. At the end of combustion, the result is directly presented by the software as percentage $(\mathrm{C} \%)$.

\subsection{Statistical analysis of data}

Analysis of variance (ANOVA) via F-test was carried out to verify significant differences in the carbon content in the compartments of different species and among compartments of the same species, in a completely randomized design with different number of replicates. In order to analyze the effect of species on compartments, i.e., whether there were differences for the same compartment within all species, treatments were the eight species and the replicates of $\mathrm{C} \%$ of the compartment under analysis per species. In order to analyze the effect of compartments on each species, i.e., whether there were differences among the four compartments within a single species, treatments were the four compartments and the replicates of $\mathrm{C} \%$ of each compartment per species.

If there were significant differences among considered variables, the Tukey-Kramer mean comparison test was used, with the help of the IBM SPSS 20.0 software in order to verify the possibility of considering an average value per species, for a group or for compartments of a species.

The basic assumptions were tested by applying ANOVA: (1) Random samples; 2) Normal distribution of the population; and (3) Variances of the homogeneous population. The Bartlett Test was used to test the

Table 2. Number of samples analyzed per compartment of the eight evaluated species in an area of Caatinga in the municipality of Floresta, state of Pernambuco, Brazil.

\begin{tabular}{|c|c|c|c|c|c|}
\hline \multirow{2}{*}{ Species } & \multirow{2}{*}{ Stem } & \multicolumn{2}{|c|}{ Branches } & \multirow{2}{*}{ Leaves } & \multirow{2}{*}{ TOTAL } \\
\hline & & Thick & Thin & & \\
\hline A. colubrina & 15 & 13 & 15 & 15 & 58 \\
\hline A. pyrifolium & 15 & 14 & 15 & 15 & 59 \\
\hline B. cheilantha & 18 & 4 & 18 & 18 & 58 \\
\hline C. quercifolius & 14 & 13 & 13 & 15 & 55 \\
\hline C. heliotropiifolius & 18 & 9 & 17 & 18 & 62 \\
\hline M. ophthalmocentra & 15 & 12 & 14 & 15 & 56 \\
\hline M. tenuiflora & 15 & 11 & 14 & 15 & 55 \\
\hline P. bracteosa & 14 & 13 & 13 & 15 & 55 \\
\hline TOTAL & 124 & 89 & 119 & 126 & 458 \\
\hline
\end{tabular}


homogeneity of variance and the Shapiro-Wilk Test (Schneider et al., 2009) was used for normality with the aid of the ASSISTAT 7.7 statistical software.

\section{RESULTS AND DISCUSSION}

The average $\mathrm{C} \%(\overline{\boldsymbol{X}})$ for stem was between 44.8 and $48.5 \%$ for P. bracteos $a$ and C. heliotropiifolius, respectively. The minimum value ( $\mathrm{min}$.) was $34.4 \%$ for M. tenuiflora and the maximum value (max.) was $57.6 \%$ for C. heliotropiifolius. C\% variations for the stems of species were less than $10 \%$, except for $M$. tenuiflora, which presented variation coefficient (V.C.) of $12.3 \%$ (Table 3).

For thick branches, the amplitude of the mean values among species was higher than for the other compartments, varying from $40.8 \%$ for $P$. bracteosa to $47.1 \%$ for C. heliotropiifolius. With the exception of B. cheilantha, the minimum content for thick branches was less than $40 \%$. C. quercifolius presented maximum content of $53.7 \%$. V.C. values of this compartment presented values between 6.1 and 13.7\% (Table 3).

The average $\mathrm{C} \%$ of thin branches varied from $45.2 \%$ for C. quercifolius to $47.8 \%$ for M. ophthalmocentra and M. tenuiflora. C. heliotropiifolius presented the lowest value (37.2\%) and M. ophthalmocentra the highest value (55.6\%). This compartment presented V.C. values between 3.3 and $8.9 \%$, in which species B. cheilantha, C. quercifolius, $M$. ophthalmocentra, $M$. tenuiflora and P. bracteosa presented compartments with the lowest variation (Table 3 ).

Finally, the leaves of the eight species presented average $\mathrm{C} \%$ ranging from $43.0 \%$ for C. heliotropiifolius to $49.1 \%$ for $A$. colubrina. Minimum and maximum values were $34.2 \%$ and $57.3 \%$ for $A$. pyrifolium and C. heliotropiifolius, respectively. V.C. of this compartment was between 7.3 and $14.0 \%$, as A. colubrina, A. pyrifolium, C. heliotropiifolius, M. ophthalmocentra and P. bracteosa were the compartments with the greatest variation among all analyzed compartments (Table 3), being responsible for the plant primary productivity. There are no data to attribute the causes for this greater variation in the carbon content in leaves, which may be due to the influence of environmental factors of the region and/or physiological factors in each species, which should be better investigated.

Dispersion with respect to the mean values expressed by the variation coefficient was low for compartments of the eight species, with amplitude of only 3.0 to $14 \%$ (Table 3 ), evidencing that $\mathrm{C} \%$ behaves in a similar way among individuals of the same species. Low dispersion in the carbon content of different species and plant parts has been reported in other studies (Elias \& Potvin, 2003; Thomas \& Malczewski, 2007; Vieira et al. 2009; Thomas \& Martin, 2012; Pereira et al., 2016), reaching values up to $38 \%$ such as those recorded by Navarro et al. (2013).

The average C\% values found in this study were lower than $50 \%$ (Table 3), which is a conventional value widely used in studies to estimate carbon stock in plants (Ma et al., 2017). It is also common to find values lower than 50\% in other forest phytophysiognomies (Weber et al., 2006; Dalla Corte \& Sanquetta, 2007; Balbinot et al. 2008; Vieira et al., 2009; Dallagnol et al., 2011; Watzlawick et al., 2011; Mello et al. 2012; Yeboah et al., 2014; Pereira et al., 2016; Ma et al., 2017).

Table 3. Descriptive statistics of carbon contents (C\%) in the four compartments of the eight species evaluated in an area of Caatinga in the municipality of Floresta, state of Pernambuco, Brazil.

\begin{tabular}{|c|c|c|c|c|c|c|c|c|c|c|c|c|c|c|c|c|}
\hline \multirow[b]{2}{*}{ Species } & \multicolumn{4}{|c|}{ Stem } & \multicolumn{4}{|c|}{ Thick branches } & \multicolumn{4}{|c|}{ Thin branches } & \multicolumn{4}{|c|}{ Leaves } \\
\hline & $\| x$ & $\dot{\Xi}$ & 离 & $\underset{>}{ن}$ & $\forall$ & $\dot{\Xi}$ & 总 & ن & 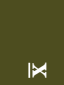 & $\dot{\Xi}$ & 离 & $\stackrel{ن}{ن}$ & $\| x$ & $\dot{\Xi}$ & 兰 & $\stackrel{ن}{>}$ \\
\hline A. colubrina & 46.6 & 44.1 & 49.4 & 4.1 & 45.8 & 39.9 & 52.7 & 6.1 & 47.5 & 43.6 & 53.5 & 6.6 & 49.1 & 39.2 & 56.5 & 8.7 \\
\hline A. pyrifolium & 47.4 & 42.1 & 53.2 & 7.0 & 44.8 & 36.8 & 49.0 & 8.5 & 45.9 & 42.1 & 54.0 & 7.3 & 47.1 & 36.8 & 57.3 & 11.5 \\
\hline B. cheilantha & 46.1 & 40.7 & 51.2 & 6.0 & 44.6 & 40.7 & 49.2 & 7.9 & 47.5 & 42.9 & 48.6 & 3.3 & 44.7 & 38.6 & 51.4 & 7.3 \\
\hline C. quercifolius & 46.8 & 42.7 & 54.2 & 6.4 & 44.4 & 35.5 & 53.7 & 12.4 & 45.2 & 39.9 & 48.8 & 5.3 & 44.3 & 40.3 & 49.6 & 8.9 \\
\hline C. heliotropiifolius & 48.5 & 40.9 & 57.6 & 8.0 & 47.1 & 39.1 & 53.0 & 9.2 & 45.8 & 37.2 & 52.6 & 8.9 & 43.0 & 34.2 & 54.9 & 14.0 \\
\hline M. ophthalmocentra & 47.5 & 42.9 & 54.4 & 7.8 & 45.2 & 39.3 & 52.8 & 9.5 & 47.8 & 42.2 & 55.6 & 6.7 & 45.5 & 38.2 & 52.8 & 10.2 \\
\hline M. tenuiflora & 47.4 & 34.4 & 56.5 & 12.3 & 43.7 & 36.2 & 51.3 & 13.7 & 47.8 & 40.8 & 53.3 & 3.0 & 46.6 & 35.5 & 52.7 & 12.7 \\
\hline P. bracteosa & 44.8 & 42.7 & 48.1 & 3.6 & 40.8 & 35.5 & 46.5 & 7.2 & 46.0 & 43.0 & 52.5 & 4.9 & 48.1 & 37.0 & 51.0 & 8.5 \\
\hline
\end{tabular}

Variation coefficient (V.C.). 
However, species with average C\% below 50\% are not common. In reviewing 31 studies on $\mathrm{C} \%$ in the stem of 253 species in different biomes, Thomas \& Martin (2012) found average values higher than $50 \%$ in conifers of Subtropical/Mediterranean and Temperate/Boreal Forests. Navarro et al. (2013) also detected mean values of up to $55 \%$ in tropical species distributed in different succession stages in Costa Rica. Studying the six main species of the Boreal Forest of North America, Gao et al. (2016) found values between $49.0 \pm 0.1 \%$ and $53.0 \pm 0.3 \%$ for stems. For Thomas \& Malczewski (2007), the average C\% of the 3 conifer species is $50.82 \pm 0.09$, while that of the 11 angiosperm species is $49.49 \pm 0.21 \%$. However, there were some angiosperm species that had individual average values higher than 50\%. Even with these differences in the carbon content among different species, regions and typologies, comparisons should be made with caution, since the methodology used in each study varied and can influence the final result.

ANOVA for the same compartments of the eight species found that the mean values among species for stem and thin branches do not differ from each another, thus accepting $\mathrm{H}_{0}$, while $\mathrm{H}_{0}$ was rejected for thick branches and leaves and at least two or more species differ from each other in relation to $\mathrm{C} \%$ at $5 \%$ probability level (Table 4).
In comparison within species, or among the compartments of the same species, $\mathrm{H}_{0}$ was rejected for C. heliotropiifolius and P. bracteosa and the mean values of at least two compartments of these two species differ from each other at $1 \%$ probability level (Table 4 ).

According to the Tukey-Kramer mean test for C\% of compartments among species, statistical difference was observed for thick branches in C. heliotropiifolius and P. bracteosa. Differences for leaves were found between A. colubrine and C. heliotropiifolius. Analyzing $\mathrm{C} \%$ among species, it was observed that variations for C. heliotropiifolius only occurred between stem and leaf compartments, while $P$. bracteosa presented significant differences for $\mathrm{C} \%$ of stem, thick branches and leaves, and thin branches differed only from thick branches (Table 5).

The use of average carbon content value of $46.4 \%$ for A. colubrina, A. pyrifolium, B. cheilantha, C. quercifolius, $M$. ophthalmocentra and $M$. tenuiflora is recommended, with no separate values for compartments, considering that there were no significant differences among these species. In practice, each ton of dry biomass per hectare $\left(\mathrm{Mg}_{\mathrm{g}} \mathrm{ha}^{-1}\right)$ for this group of Caatinga species will correspond to $0.464 \mathrm{Mg}^{-h a^{-1}}$ of carbon, referring to $\mathrm{CO}_{2 \mathrm{eq}}$ stock of $1.7 \mathrm{Mg} \cdot \mathrm{ha}^{-1}$ (value obtained by multiplying the amount of carbon by factor 3.67, which is based

Table 4. Results of ANOVA F-test of carbon contents (C\%) among compartments of the eight species and among the different compartments within species in an area of Caatinga in the municipality of Floresta. state of Pernambuco, Brazil.

\begin{tabular}{|c|c|c|c|c|}
\hline \multicolumn{5}{|c|}{ EFFECT OF SPECIES ON COMPARTMENTS } \\
\hline Compartments & $F$-value & $\begin{array}{c}F \text {-critical } \\
(5 \%)\end{array}$ & $\begin{array}{c}F \text {-critical } \\
(1 \%)\end{array}$ & $p$-value \\
\hline Stem & $1.551^{n s}$ & 2.089 & 2.796 & 0.1571 \\
\hline Thick branches & $2.126^{*}$ & 2.125 & 2.868 & 0.0499 \\
\hline Thin branches & $0.482^{n s}$ & 2.087 & 2.793 & 0.8459 \\
\hline Leaves & $2.728^{*}$ & 2.087 & 2.793 & 0.0116 \\
\hline \multicolumn{5}{|c|}{ EFFECT OF COMPARTMENTS ON SPECIES } \\
\hline Species & $F$-value & $\begin{array}{c}\text { F-critical } \\
(5 \%)\end{array}$ & $\begin{array}{c}\text { F-critical } \\
(1 \%)\end{array}$ & $p$-value \\
\hline A. colubrina & $2.659^{n s}$ & 2.776 & 4.167 & 0.0574 \\
\hline A. pyrifolium & $1.226^{n s}$ & 2.766 & 4.145 & 0.3086 \\
\hline B. cheilantha & $2.008^{n s}$ & 2.776 & 4.167 & 0.1237 \\
\hline C. quercifolius & $1.358^{n s}$ & 2.786 & 4.191 & 0.2665 \\
\hline C. heliotropiifolius & $4.261^{* *}$ & 2.764 & 4.138 & 0.0086 \\
\hline M. ophthalmocentra & $0.946^{n s}$ & 2.783 & 4.182 & 0.4253 \\
\hline M. tenuiflora & $1.082^{n s}$ & 2.786 & 4.191 & 0.3649 \\
\hline P. bracteosa & $15.126^{\star *}$ & 2.786 & 4.191 & $<0.0001$ \\
\hline
\end{tabular}

Where: ${ }^{* *}=$ significant at $1 \%$ probability level $(p-$ value $<0.01) ;{ }^{*}=$ significant at $5 \%$ probability level $(0.01 \leq p$-value $<0.05)$ and $n s=$ not statistical significant $(p$-value $\geq 0.05)$. 
Table 5. Comparison of the average carbon contents $(\mathrm{C} \%)$ of compartments among and within each species that showed significant differences by ANOVA in an area of Caatinga in the municipality of Floresta. state of Pernambuco, Brazil.

\begin{tabular}{lllll}
\multirow{2}{*}{ Species } & Stem & \multicolumn{2}{c}{ Branches } & Leaves $^{*}$ \\
\cline { 2 - 3 } & & Thick & Thin & \\
A. colubrina & $46.6 \mathrm{Aa}$ & $45.9 \mathrm{ABa}$ & $47.5 \mathrm{Aa}$ & $49.0 \mathrm{~A} \mathrm{a}$ \\
C. heliotropiifolius & $48.5 \mathrm{Aa}$ & $47.1 \mathrm{~A} \mathrm{a} \mathrm{b}$ & $45.8 \mathrm{Aab}$ & $43.0 \mathrm{~B} \mathrm{~b}$ \\
P. bracteosa & $44.8 \mathrm{~A} \mathrm{~b}$ & $40.8 \mathrm{~B} \mathrm{c}$ & $46.0 \mathrm{Aab}$ & $48.1 \mathrm{~A} \mathrm{Ba}$ \\
\hline
\end{tabular}

* Means followed by the same capital letter in the column and lower case letter in the row do not differ significantly by the the Tukey-Kramer test at $5 \%$ probability level.

on the molecular weights of carbon and oxygen), which is equivalent to 1.7 carbon credits per hectare, as by convention, each carbon credit is equivalent to one ton of $\mathrm{CO}_{2 \mathrm{eq}}$.

The mean values of $48.5 \%, 46.0 \%$ (intermediate value) and $43.0 \%$ for stem, thick and thin branches and leaves, respectively, should be used for $C$. heliotropiifolius. The indicated values for $P$. bracteos $a$ are $44.8 \%, 40.8 \%$, $46.0 \%$ and $48.1 \%$ for stem, thick branches, thin branches and leaves, in that order, with the need to obtain information of dry biomass per hectare per compartment, so that carbon credit estimates for these species can be carried out.

Studies analyzing the carbon content of these eight specific species were not found for comparison and it is believed that this study is pioneer, mainly due to the sampling level performed. For other Caatinga species, Vieira et al. (2009) analyzed leaf, branch, root, bark and stem samples of 30 species and found average values of $47.4 \%, 44.7 \%, 44.4 \%, 43.7 \%$ and $44.6 \%$, respectively, in which the $\mathrm{C} \%$ of leaves were the highest in relation to the other plant parts. According to the authors, this is due to the use of carbon in metabolic processes and the immediate allocation of this element in leaves. The only species that exhibited this behavior in the present study were A. colubrina and P. bracteosa, indicating that higher concentration in leaves is not standard among all species.

Pereira et al. (2016) analyzed C\% in the arboreal component of 18 species, litterfall, herbaceous and roots (fine, medium and thick) of a Caatinga area undergoing regeneration process for 30 years in the state of Ceará, and reported values of $44.53 \pm 1.88 \%$, $42.76 \pm 0.77 \%, 38.17 \pm 0.25 \%, 30.87 \pm 0.76 \%, 43.50 \pm 0.13 \%$ and $45.11 \pm 0.24 \%$, respectively. The $\mathrm{C} \%$ of the tree component corroborates findings obtained in the present study. The authors attribute the low levels of the herbaceous component and fine roots (which differed from the others) to the rapid growth, and consequently their low specific density.

The statistical equality for the average C\% of the compartments of six species analyzed, which provided the use of a single mean value (46.4\%), is a result of extreme relevance and allows estimating the potential carbon sequestration in the Caatinga. Grouping certain species into different typologies due to statistical similarities for $\mathrm{C} \%$ in one or more tree compartments has already been suggested in other studies (Weber et al., 2006; Vieira et al. 2009; Dallagnol et al., 2011; Watzlawick et al., 2011; Pereira et al., 2016). However, this species grouping is not a common result found for all vegetation phytophysiognomies. Ma et al. (2017) carried out a bibliographic and statistical analysis on the C\% information of 4,318 global species and found significant differences in levels found for roots, leaves, trunk and reproductive organs, indicating the need to analyze the carbon content per compartment in each species.

In addition to the different compartments and species, other factors that were not considered in this study are described in literature as having potential to influence the carbon variation, and some examples are: the successional stage of the analyzed vegetation (Navarro et al., 2013), the biome to which it belongs (Elias \& Potvin, 2003; Thomas \& Martin, 2012), conifer or angiosperm species (Thomas \& Malczewski, 2007; Thomas \& Martin, 2012; Ma et al., 2017), internal position of the stem (Yeboah et al., 2014), young or latewood (Lamlom \& Savidge, 2003), the shade tolerance of the species (Gao et al., 2016), life forms (Pereira et al., 2016; Ma et al., 2017), growth rate and specific wood density (Elias \& Potvin, 2003; Martin \& Thomas, 2011; Becker et al, 2012).

In the case of specific wood density, some studies have indicated high correlation (86\%) with the carbon 
contents of species (Elias \& Potvin, 2003), while other studies have found no relationship (Thomas \& Malczewski, 2007). According to Moreschi (2012), wood is a product of nature under continuous development, not providing fixed measurements or and constant values, and its density is the result of the countless external (geographical location, climate, soil, site index, altitude, declivity, wind, spacing, species association and silvicultural methods) and internal influences (moisture, early and late wood, width of growth rings and trunk position), which act on the organization and dimensions of wood cells.

Incorporating specific average $\mathrm{C} \%$ for all species in carbon market projects remains a challenge due to the difficulty in obtaining them, as well as the great diversity of species recorded in the different biomes. Despite the limitation regarding the number of species in this study (only eight), it was possible to incorporate the average $\mathrm{C} \%$ values described in projects aimed at the carbon market in the Caatinga biome and avoid the use of a general fixed value, without considering differences within species and between species and environment, which can lead to under or overestimated carbon stock values.

\section{CONCLUSIONS}

The hypothesis of this study was partially denied, considering that it is possible to use a single carbon content value (46.4\%) for A. colubrina, A. pyrifolium, B. cheilantha, C. quercifolius, $M$. ophthalmocentra and $M$. tenuiflora without the need for distinctions for stem, branches and leaves.

While mean values of $48.5 \%, 46.0 \%, 46.0 \%$ and $43.0 \%$ should be used for C. heliotropiifolius, the indicated values for P. bracteosa are $44.8 \%, 40.8 \%, 46.0 \%$ and $48.1 \%$ for stem, thick branches, thin branches and leaves, respectively.

Further studies should be carried out to verify the level of influence of specific wood density and other internal factors of plants, as well as environmental factors, on the average carbon content of these eight species.

\section{ACKNOWLEDGEMENTS}

The authors wish to thank CNPq (Conselho Nacional de Desenvolvimento Científico e Tecnológico), FACEPE (Fundação de Amparo à Ciência e Tecnologia do Estado de Pernambuco), CAPES (Coordenação de Aperfeiçoamento de Pessoal de Nível Superior) and UFRPE (Universidade Federal Rural de Pernambuco) for grant funding for this research. We would also like to thank Agrimex S.A. for permission to access the area to conduct the Research and IFPE (Instituto de Ciência e Tecnologia de Pernambuco) for support in the development of this study.

\section{SUBMISSION STATUS}

Received: 18 may, 2017

Accepted: 24 jan., 2018

\section{CORRESPONDENCE TO}

\section{Mayara Dalla Lana}

Curso Técnico em Meio Ambiente, Instituto

Federal de Ciência e Tecnologia de Pernambuco

- IFPE, Rua Padre Agobar Valença, s/n,

Severiano Morais Filho, CEP 55299-390,

Garanhuns, PE, Brasil

e-mail: mayara.dallalana@garanhuns.ifpe.edu.br

\section{FINANCIAL SUPPORT}

Fundação de Amparo à Ciência e Tecnologia do Estado de Pernambuco.

\section{REFERENCES}

Alves AR, Ferreira RLC, Silva JAA, Dubeux JCB Jr, Osajima JA, Holanda AC. Conteúdo de nutrientes da biomassa e eficiência nutricional em espécies da Caatinga. Ciência Florestal 2017; 27(2): 377-390. http://dx.doi. org/10.5902/1980509827686.

Alves FT Jr, Ferreira RLC, Silva JAA, Marangon LC, Cespedes GHG. Regeneração natural de uma área de caatinga no sertão Pernambucano, nordeste do Brasil. Cerne 2013; 19(2): 229-235. http://dx.doi.org/10.1590/ S0104-77602013000200006.

Angiosperm Phylogeny Group III - APG III. An update of the angiosperm phylogeny group classification for the orders and families of flowering plants. Botanical Journal of the Linnean Society 2009; 161(2): 105-121. http://dx.doi. org/10.1111/j.1095-8339.2009.00996.x.

Balbinot R, Valério AF, Sanquetta CR, Caldeira MVW, Silvestre R. Estoque de carbono em plantações de Pinus spp. em diferentes idades no sul do estado do Paraná. Floresta 2008; 38(2): 318-324. http://dx.doi.org/10.5380/ rf.v38i2.11626. 
Becker GS, Braun D, Gliniars R, Dalitz H. Relations between wood variables and how they relate to tree size variables of tropical African tree species. Trees (Berlin) 2012; 26(4): 1101-1112. http://dx.doi.org/10.1007/s00468-012-0687-6.

Brasil. Ministério de Ciência e Tecnologia - MCT. Estimativas anuais de emissões de gases do efeito estufa no Brasil. 2nd ed. Brasília: MCT; 2014.

Brown S. Mitigation potential of carbono dioxide emissions by management of forest in Asia. Ambio 1996; 25: 273-278.

Comitê Técnico Científico da Rede de Manejo Florestal da Caatinga. Rede de manejo florestal da Caatinga: protocolo de medições de parcelas permanentes. Recife: APNE-Associação Plantas do Nordeste; 2005.

Dalla Corte AP, Sanquetta CR. Quantificação do estoque de carbono fixado em reflorestamentos de Pinus na área de domínio da Floresta Ombrófila Mista no Paraná. Cerne 2007; 13(1): 32-39.

Dallagnol FS, Mognon F, Sanquetta CR, Corte APD. Teores de carbono de cinco espécies florestais e seus compartimentos. Floresta e Ambiente 2011; 18(4): 410-416. http://dx.doi.org/10.4322/floram.2011.060.

Elias M, Potvin C. Assessing inter- and intra-specific variation in trunk carbon concentration for 32 neotropical tree species. Canadian Journal of Forest Research 2003; 33(6): 1039-1045. http://dx.doi.org/10.1139/x03-018.

Empresa Brasileira de Pesquisa Agropecuária - EMBRAPA. Sistema brasileiro de classificação de solos. 3rd ed. Rio de Janeiro: Embrapa; 2011.

Gao B, Taylor AR, Chen HYH, Wang J. Variation in total and volatile carbon concentration among the major tree species of the boreal forest. Forest Ecology and Management 2016; 375: 191-199. http://dx.doi. org/10.1016/j.foreco.2016.05.041.

Giulietti AM, du Bacage AL Na, Castro AAJF, GamarraRojas CFL, Sampaio EVSB, Virginio JF et al. Diagnóstico da vegetação nativa do bioma Caatinga. In: Silva JMC, Tabarelli M, Fonseca MT editores. Biodiversidade da caatinga: áreas e ações prioritárias para a conservação. Brasília: Ministério do Meio Ambiente; 2004.

Gonzalez P, Kroll B, Vargas CR. Tropical rainforest biodiversity and aboveground carbon changes and uncertainties in the Selva Central, Peru. Forest Ecology and Management 2014; 312: 78-91. http://dx.doi.org/10.1016/j. foreco.2013.10.019.

Instituto Brasileiro de Geografia e Estatística - IBGE. Manual técnico da vegetação brasileira. 2 nd ed. Rio de Janeiro: IBGE; 2012.

Koehler HS, Watzlawick LF, Kirchner FF, Valério AF. Fontes de erros nas estimativas de biomassa e carbono fixado na Floresta Ombrófila Mista. Biomassa \& Energia 2005; 2(1): 69-77.

Laiho R, Laine J. Tree stand biomass and carbon content in an age sequence of drained pine mires in southern
Finland. Forest Ecology and Management 1997; 93(1-2): 161-169. http://dx.doi.org/10.1016/S0378-1127(96)03916-3.

Lamlom SH, Savidge RA. A reassessment of carbon content in wood: variation within and between 41 North American species. Biomass and Bioenergy 2003; 25: 381-388.

Lima RB, Bufalino L, Alves FT Jr, Silva JAA, Ferreira RLC. Diameter distribution in a Brazilian tropical dry forest domain: predictions for the stand and species. Anais da Academia Brasileira de Ciências 2017; 89(2): 1189-1203. http://dx.doi.org/10.1590/0001-3765201720160331. PMid: 28640356

Ma S, He F, Tian D, Zou D, Yan Z, Yang Y et al. Variations and determinants 1 of carbon content in plants: a global synthesis. Biogeosciences Discussions 2017; 14: 1-22. http:// dx.doi.org/10.5194/bg-2017-322.

Martin AR, Thomas SC. A reassessment of carbon content in tropical trees. PloS One 2011; 6(8): e23533:1-e23533:9. http://dx.doi.org/10.1371/journal.pone.0023533.

Mello AA, Nutto L, Weber KS, Sanquetta CR, Matos JLM, Becker G. Individual biomass and carbon equations for Mimosa scabrella Benth. (Bracatinga) in Southern Brazil. Silva Fennica 2012; 46(3): 333-343. http://dx.doi. org/10.14214/sf.44.

Moreschi JC. Propriedades da madeira. 4th ed. Curitiba: UFPR; 2012.

Navarro M, Moya R, Chazdon R, Ortiz E, Vilchez B. Successional variation in carbon content and wood specific gravity of four tropical tree species. Bosque (Valdivia) 2013; 34(1): 33-43.

Pereira LR Jr, Andrade EM, Palácio HAQ, Raymer PCL, Ribeiro JC Fo, Pereira FJS. Carbon stocks in a tropical dry forest in Brazil. Revista Ciência Agronômica 2016; 47(1): 32-40. http://dx.doi.org/10.5935/1806-6690.20160004.

Sampaio EVS, Costa TL. Estoques e fluxos de carbono no semi-árido nordestino: estimativas preliminares. Revista Brasileira de Geografia Física 2011; 6: 1275-1291.

Sampaio EVSB. Caracterização do bioma Caatinga. In: Gariglio MA, Sampaio EVSB, Cestaro LA, Kageyama PY, editores. Uso sustentável e conservação dos recursos florestais da Caatinga. Brasília: Serviço Florestal Brasileiro; 2010.

Sanquetta CR. Métodos de determinação de biomassa florestal. In: Sanquetta CR, Watzlawick LF, Balbinot R, Ziliotto MAB, Gomes FS, editores. As florestas e o carbono. Curitiba: Editora UFPR; 2002.

Schneider PR, Schneider PSP, Souza CAM. Análise de regressão aplicada à Engenharia Florestal. 2nd ed. Santa Maria: FCAOS; 2009.

Thomas SC, Malczewski G. Wood carbon content of tree species in Eastern China: interspecific variability and the importance of the volatile fraction. Journal of Environmental Management 2007; 85(3): 659-662. http:// dx.doi.org/10.1016/j.jenvman.2006.04.022. PMid:17187921. 
Thomas SC, Martin AR. Carbon content of tree tissues: a synthesis. Forests 2012; 3(2): 332-352. http://dx.doi. org/10.3390/f3020332.

Vieira G, Sanquetta CR, Klüppel MLW, Barbeiro LSS. Teores de carbono em espécies vegetais da Caatinga e do Cerrado. Revista Acadêmica Ciências Agrárias Ambientais 2009; 7(2): 145-155.

Watzlawick LF, Ebling AA, Rodrigues AL, Veres OJI, Lima AM. Variação nos teores de carbono orgânico em espécies arbóreas da floresta ombrófila mista. Floresta e
Ambiente 2011; 18(3): 248-258. http://dx.doi.org/10.4322/ floram.2011.045.

Weber KS, Balbinot R, Watzlawick LF, Sanquetta CR. Teores de carbono orgânico de seis espécies naturais do ecossistema da floresta ombrófila mista. Ambiência 2006; 2(2): 167-177.

Yeboah D, Burton AJ, Storer AJ, Opuni-Frimpong E. Variation in wood density and carbon content of tropical plantation tree species from Ghana. New Forests 2014; 45(1): 35-52. http://dx.doi.org/10.1007/s11056-013-9390-8. 